\title{
AN EMPIRICAL INVESTIGATION OF THE INDICATORS OF GOVERNANCE AND INSECURITY IN NIGERIA: 1984-2018
}

\author{
Hadi Aminu \\ Department of Economics and Development Studies, \\ Federal University Dutsin-Ma, Katsina State - Nigeria \\ Email: ahadi@fudutsinma.edu.ng/aminuhadi85@gmail.com
}

\author{
Alhassan Mohammed Aminu \\ Department of Economics and Development Studies, \\ Federal University Dutsin-Ma, Katsina State - Nigeria \\ Email: maalhassn@fudutsinma.edu.ng/alhassanmohammed58@yahoo.com
}

\author{
Corresponding Author Email: alhassanmohammed58@yahoo.com
}

\begin{abstract}
Governance particularly poor governance is a syndrome that is incentivizing security crime in Nigeria and that has constituted impediments to the Nigerian development process. In this regard, this study decentralises governance to its six indicators namely: government accountability; government stability and absence of internal conflicts; control of corruption; bureaucratic quality and rule of law and therefore investigating the impact of each of the six indicators on insecurity in Nigeria. The study utilized Johansen Cointegration and FMOLS to essentially reveal that, poor nature of all of the six indicators of governance except absence of internal conflicts impacts positively on insecurity in Nigeria. Also, among all the poor five indicators that impact positively on insecurity, corruption, government accountability and rule of law are of significant positive impact on insecurity in Nigeria. The study therefore concluded that the bad shape of the indicators of governance contribute to the weak governance system that consequently exacerbate insecurity situation in Nigeria. The study then recommends among others, strengthening and advancing the Nigerian anti-corruption war to match the changing ways of perpetrating corruptions by public office holders particularly officers of the Nigerian security departments should be strictly enforced so as to abate the upsurge of corruption among public office holders thereby suppressing the hiking level of insecurity in the country due to corruption; ensuring full application of law on the insecurity culprits irrespective of the social status and connections so as to serve as deterrent to other defiant in the mix of conformists in the society.
\end{abstract}

Keywords: Insecurity and Governance indicators. 


\section{Introduction}

Governance is a concept regarded as emotive power to the flourishing of any formally organised society (Herbert and Michael, 2014). This is because no society can attain greatness without full entrenchment and enforcement of governance (good). Unfortunately, Nigeria has over the years been enmeshed with the problem of governance and that has set a retrogressive path to the advancement of the country as most of the social problems such as unemployment, poverty, inequality and insecurity, among others plaguing the country are products of governance problem in Nigeria (Human Right Report, 2010).

Admittedly, Olaniyi and Ikechukwu (2019) expressed that the violent crime and insecurity generally are consequence of pervasive corruption and abandonment of governance in Nigeria. In this connection, security crimes have assumed dangerous shape that is continually threatening the socio-economic progress of this country (Olaniyi and Ikechukwu, 2019). Factually speaking, the effects of insecurity phenomenon in Nigeria are clearly viewed in the losses of lives and properties due to heinous acts of various forms of life threatening crimes like militancy, terrorism and banditry attacks, among others which are major drawbacks for the growth and development to the Nigerian economy (Evans and Kelikume, 2018). For instance, Osagie, Fred and Samuel (2010) pointed that governance problem which exhibited the denial of the people of the Niger-Delta region the benefits of oil proceeds, uncared for large population wandering without job to do in north-eastern Nigeria and inability of responsible authority to make provision for sound educational system for rural communities particularly Fulani living in the hinterlands, among others, were the main causes responsible for violent uproar leading to high tense of insecurity in the country particularly in the aforementioned regions.

Concisely, available studies suggested that the cause of insecurity in Nigeria is attributed to social, economic and political factors such as poverty, unemployment, inequality, corruption and poor governance (e.g Olawale, 2003; Ikelegbe, 2006; Olaniyi and Ikechukwu, 2019). However, until recent time, studies on the causes of the various forms of security crimes like Niger Delta militancy, Boko Haram terrorism and herdsmen attacks still remained inexhaustibly empirically researched upon; while the study on the nexus between insecurity and governance in Nigeria still mostly remained conceptual. This severe scarcity of empirical research may be ascribed as the key source of inadequate policy direction on how to halt the outbreak of violent attacks and insecurity in the country. Consequently, this study seeks to fill the gap by examining the impact of governance on insecurity in Nigeria.

Following the introduction to the study given in the preceding section, section 2 shall present definition of key concepts, review of empirical literature pertinent to the study and theoretical framework underpinning the study. Section 3 shall deal with the methodology of the study. Section 4 shall consist of results presentation and discussion of findings; while section 5 completes the study with summary, conclusion and recommendations. 


\section{Literature Review}

\subsection{Definition of Key Concepts}

\subsubsection{Insecurity}

The concept of insecurity is a familiar concept to human societies that haveexisted even in the primitive societies of the world. While some scholars perceived from the angle of absence of safety, others perceived insecurity from the dimension of socio-economic perspectives. Consequently, Adamu and Rasheed (2016) cited Beland (2015) that "insecurity is the state of fear and anxiety breeding from a real or assumed absence of safety" (p. 1). Also, Achumba, Ighomereho, and Akpan-Robaro (2013) define insecurity as lack of defence or safety which further entails peril; death-trap; ambiguity; dearth of fortification, and lack of security. Likewise, Buzan (1991) conceived insecurity from the dimension of political, economic, social and environment that exerts threats and distress on the individual and the state at both national and international levels. Form the foregoing, the Buzan definition of insecurity encompasses insecurity in major facets of human undertakings and therefore, insecurity can be said to be an intimidating element that prevents an advancement of human in his pursuit of social and economic well-being. Consequently, this study adopted the Buzan definition of insecurity for encompassing major elements of insecurity in the face of human endeavours.

\subsubsection{Governance}

Generally speaking, governance is a way and manner of exercising authority in the administration and management of social, economic and political affairs in the country by the responsible institutions with view to ensure full entrenchment of accountability, transparency and broad-based participation in the government system (Ibrahim, 2013). In this way, International agencies like United Nations Development (UNDP), the World Bank, Organisation for Economic Co-operation and Development (OECD), Development Assistance Committee (DAC) and others, defined governance as the exercise of authority or power in order to manage a country's economic, political and administrative affairs.

Also, International Bureau of Education (IBE), a sister agency of United Nations Education, Science and Cultural Organisation (UNESCO) defined governance to mean structures and processes that are designed to ensure accountability, transparency, responsiveness, rule of law, stability, equity and inclusiveness, empowerment, and broad-based participation. From the foregoing, this study adopted the IBE definition as a working definition of governance for explicitly included most of the dimension of governance.

\subsection{Historical Overview of Insecurity in Nigeria}

The trials of insecurity in Nigeria can be traced back to the early years of military rule when large numbers of arms were imported into the country for the use of the military during and after the Nigerian civil war, some of which slipped into the hands of civilians and became items in their possessions owing to poor transparency and accountability in the country (Ewetan and Urhie, 2014).Similarly, improper records keeping, mishandling and poor custodian of these arms by Nigerian security department due to disobedience to the rule of law had led many civilians and ex-military men to exploit them for mischievous purposes such as armed robbery, house burglaries, and physical assaults, among others, soon after the civil war in Nigeria was brought to an end in early 1970s and even in the present time. 
Admittedly, it is observed that the level of insecurity in Nigeria has since the return to democratic government in May, 1999 increased woefully. This is induced by recurrent communal clashes, ethnic/tribal conflicts, religious riots/conflicts, militancy and ritual killings, cultism and ethnic militia attacks and the farmers-herdsmen conflicts that are not followed by the full application of law on the culprits (Akinola, 2016). The situation of insecurity has also witnessed the birth of the Boko haram insurgency in the North-eastern Nigeria in 2009 and subsequent transformation of farmers-herders clashes into banditry and cattle rustling from 2010 till present (Ladan, 2019). Most importantly, in some states of the north, the farmersherders form of insecurity has further transformed not only to banditry and cattle rustling but also to kidnapping of people for ransom. Concisely, as cited in Onime (2018), Nigeria is by the incident of governance problems presently bedevilled by a plethora of civil unrests and insecurity including but not limited to the following:

(i) Armed robbery

(ii) Kidnapping and Ritual killings

(iii) High profile murder and political assassinations

(iv) Herdsmen disturbances and clashes with farmers

(v) Violent agitations for resource control especially, in the Niger Delta region of Nigeria

(vi) Non-violent agitations for self-determination as observed in the South-east Nigeria

(vii) Terrorist attacks epitomized by Boko Haram in the North-east Nigeria

(viii) Ethnic and Religious tensions

(ix) Communal and land disputes typified by Aguleri-Umuleri crises in Anambra State; and

(x) Political/post-election violence, among others.

It is noteworthy that several reasons have been ascribed for the spate of different form of insecurity in Nigeria and this includes over reliance on oil, over dependence on public job by citizens, export of primary commodities, social inequality, state failure, human right violations, resource predation, corruption, feeling of marginalization and alienation, among others which can also be broadly classified as governance problem. This makes it necessary that any policy directed towards tackling insecurity must primarily address these core causes of insecurity and their constituents in order to realize the anticipated results.

\subsection{Empirical Review}

The overburden effects of governance on insecurity in Nigeria were recognized early enough in the literature. Most of the studies however, only conceptualise the subject of governance in relation to insecurity from social and political point of view, only few purely attempted the empirical examination of the concept of governance in relation to insecurity from economic perspective exist in the literature. In view of this, some of the empirical studies reviewed are:

Impact of poverty, unemployment, inequality, corruption and poor governance on Niger-Delta attacks, Boko Haram terrorism, Fulani herdsmen attacks in Nigeria by Olaniyi and Ikechukwu (2019). Employing fully modified ordinary least squares (FMOLS) estimation technique on the time series data for the variables under study, the study discovered that Niger-Delta militancy, Boko haram terrorism and herdsmen attacks in Nigeria are significantly attributed to the worsened rate of poverty, unemployment, inequality, corruption and poor state of governance in the country. Therefore, the study resolved that in agreement with the relative deprivation theory, various deprivations in the country resulted in violence and conflicts in the form of Niger-Delta militancy, Boko haram terrorism and herdsmen attacks. Thus, violence and 
security crime is as a result of governance problem as it relates to socio-economic life of citizenry in the country.

Also, study by Abdulrasheed, Amir and Matazu (2018) on Incidence and impact of cattle rustling in some rural communities in Katsina state. Inferential statistics and classical independent t-test statistics was adopted on the cross-sectional data of 1,488 respondents sampled from the eight (8) frontline local government areas of the state. The data was obtained via the use of structured questionnaire and focus group discussion in which there exist a huge variation in socio-economic variables of the respondents in the sampled local government areas between the pervasive period of the menace and the period before. The study therefore inferred that, though, there is no significant displacement and vacation of people of the rural communities, but the cattle rustling menace distort economic well-being of the people through reduction in income level.

Gabriel (2017) studied determinants of human insecurity in Nigeria and their impact on economic growth using time series data from 1994-2016. Mix methods were utilized based on the two classes of data used in the study. Autoregressive Distributed Lagged model was used as the estimation technique on the time series data; while the descriptive statistics was employed to analyse surveyed data. The study discovered that insecurity in Nigeria were mostly caused by unemployment, poverty, ethno-religious violence, terrorism, corruption, lack of specialized skills/sources of livelihood and unresolved agitations owing to inefficient system of governance. Also, the study revealed that total expenditure on security had a negative impact on GDP in both the short-run and long-run respectively due to accountability and transparency that is lacking in security expenditure. Again, corruption showed no significant impact on economic growth but a one-year lag unemployment rate and inflation rate had a significant impact on economic growth respectively. However, the analysis of the surveyed data revealed that unemployment and lack of special skills and education are significantly responsible for the heightened level of insecurity bedevilling the nation and therefore $96 \%$ of the respondents jointly agreed that job creation and skill acquisition will reduce insecurity in the country.

Similarly, Olusegun (2016) in his study "Economic growth amidst insecurity: The Nigerian experience", utilized time series data for Real GDP, Total expenditure on security, Gross Fixed Capital Formation, Total Labour Force, Corruption Perception Index and Poverty Index to show the relationship that exist between economic growth and insecurity. With the use of OLS regression method, the study reveals that expenditure on security and other related variables do not only contribute positively to economic growth in Nigeria, but their impacts on economic growth are strong and statistically significant.

Joda and Abdulrasheed (2015) studied the effect of insurgency on girls' education in North Eastern Nigeria. The study used descriptive statistics in the form of mean and standard deviation as methods of analysis of the data retrieved via structured questionnaire from sampled 180 primary and secondary schools teachers. The sample was done on the basis of 30 teachers from each state of the 6 states that constitute north-eastern region of Nigeria. The findings revealed that the insurgent attacks have affected the girls' education through mindless attacks on their schools and consequent frequent abduction of school girls from their dormitories, occasional kidnapping of school girls on their way to school; traumatic tendency of female teachers and school girls generated fears in them to going to schools.

Empirical study by Ifeanyi (2014) on "the causes and effects of insecurity in Nigeria: the challenges and relevance of the Nigerian Police Force as a panacea". Employing descriptive 
statistics in the form of frequency distribution table and percentages on the 520 retrieved questionnaires from sampled respondents, the study found that lack of accountability consciousness in Nigerian Police Force make them less-effective in tackling the current insecurity in Nigeria as shown by $86.4 \%$ of the respondents. Also, $61.4 \%$ of the respondents responded positively that insecurity in Nigeria is aggravated by the high level of poverty and unemployment owing to loss of accountability indices by those at the helms of government. Consequently upon this finding, it can be factually drawn that there is direct relationship between insecurity and indicators of governance in Nigeria.

Also, study by Abdullahi (2012) on "good governance as panacea to socio-economic crises in Nigeria". The study used descriptive statistics on the secondary data obtained from various documented sources. The findings revealed that, the absence of good governance is responsible for a lot of social and economic crises like political tension, unemployment, poverty, lack of quality education and inequitable resources allocation that further exacerbated the state of insecurity in the country since return of democratic rule in 1999 in Nigeria.

\subsection{Theoretical Framework}

The study is hinged on economic theory of crime propounded by Gray Becker (1968) and complemented by structural functionalism theory advanced by August Comte (1798-1857).

\subsubsection{Economic Theory Crime}

The economic theory of crime was propounded by Gray Becker (1968) and later expanded by Polinsky and Shavell $(2001 ; 2007)$. The theory seeks to provide a theoretical basis for linking security crime to both motive behind individual and/or gang(s) perpetrating such security crimes otherwise termed as "insecurity" against the state and criminal justice system (i.e governance system) in ensuring crime-free society, and to economically model the criminal justice system. On this note, the study shall focus more on the governance aspect of theory in relation to insecurity. Basically, the theory is an application of neoclassical theory of demand to model crime as a function of state and holds that potential criminals are economically rational, seeking to maximize utility and reacts portentously to discouraging elements by the state by ensuring stringent measures are taken against criminals (Polinsky and Shavell, 2007). Therefore, the criminals are by the principle of economic model of crime conscious of penalty pounding on criminal activities by the state through the effective governance system.

\subsubsection{Structural Functionalism Theory}

The "Structural functionalism" theory is a sociological theory advanced by August Comte (1798-1857) which viewed the society as an entity that rely on different structures or units, each of which performed a designated functions to keep and maintain the entire system. These interdependent structures or units are regarded as social institutions (of the state) that work to ensure the survival of the society (Merton, 1938). In this vein, the security unit can be viewed as a sub-unit of the societal control institution that enable sections of the society performed its "functional prerequisites" for the continued existence of its affiliates, to protect them from extermination. The roles and obligations of security sub-unit to ensure secured society or crime-free society could be looked at in two ways:

Firstly, dis-incentivized security crime like armed robbery, assassination, kidnapping, terrorism etc. and discouraged employment of individuals into the aforementioned crime as a means of 
earning a living (Global Terrorism Index, 2015; Ngwama, 2014). This is necessary for criminal activities not to be viewed as an alternative means of survival (Merton, 1938), since the chance of gaining legal employment and meeting the basic needs of life is too slim in the contemporary Nigeria.

Secondly, security sub-unit offers a lawful means of livelihood and career advancement for security personnel in their various agencies in the society. Therefore, the role of security subunits in maintaining law and order is crucial for solidity and smooth running of the society (Andersen and Taylor, 2006).

In the view of the raised points above, insecurity situations in Nigeria can be seen as a failure of institutions of the government to live up to the designated tasks in the society which lured individual criminals to bank on illegal means as an alternative to legal procedures of earning a living. Consequently, the premises laid by the structural functionalism lend critical support to the economic theory of crime by Gray Becker thereby formed the basis of establishing model for this study. Thus, the model established from the combined theories for the study is:

$\mathrm{EU}=\mathrm{U}(\mathrm{b})+\mathrm{U}(-\mathrm{f})$

Where EU stands for expected utility (more rigorously, a Von Neumann-Morgenstern expected utility function), $U$ for the utility function, $b$ is the pay-offs if anticipated from crime which is motive behind committing crime and (-f) is the penalty prescribed by the state (government) for the crime acts which is by theory expected to serve as disincentive to the criminal acts.

\section{Methodology \\ 3.1 Data Source and Variable Description}

The study utilized annual time series data covering the periods 1986 to 2018 . The choice was warranted by the availability of data. The data was sourced from International Country Risk Guide (ICRG, 2016) and statistical bulletin of Central Bank of Nigeria (CBN, 2016) though, the dataset obtained from both sources stopped at 2016 and that necessitated the use of four years forward moving average to generate the series for 2017 and 2018 to make up the dataset to 2018. As cited in Tharanga (2018), World Governance Indicator (WGI) measured governance using six indicators such as government stability and absence of internal conflicts, government accountability, bureaucratic quality, corruption and rule of law (law and order). Consequently, this study disbanded the governance to the aforementioned indicators used in Tharanga (2018) to explicitly investigate the impacts of each of the indicator of governance on insecurity in Nigeria. The data index for the indicators of the governance is ranked from one (1) to ten (10) with one (1) depicting high level of indicator and ten (10) depicts low level of indicator.

\subsection{Model Specification}

Flowing from the theoretical frameworks underpinning the work, model meant to examine the impact of governance on insecurity in Nigeria is specified as:

$E U=f(b,-g)$ 
Where EU is expected satisfaction from the criminal acts; $b$ is expected payoffs from crime act while; $-\mathrm{g}$ is punishment to the criminal acts. Substituting the variable of interest into the equation 3.1, the functional form of model for the study would be:

INS. $\mathrm{f}($ gov.-i)

Where: INS. is insecurity and gov.-i is governance indicators.

Splitting governance to its major six indicators, the equation 3.2 shall be restated as:

INS. $=\mathrm{f}(\mathrm{GSTB}, \mathrm{GACT}, \mathrm{AIC}, \mathrm{BQLT}, \mathrm{COR}, \mathrm{RoL})$

Where: INS. is insecurity; GSTB is government stability, GACT is government accountability; AIC is absence of internal conflict; BQLT is bureaucratic quality; COR is corruption and; RoL is rule of law (i.e law and order).

\subsection{Model estimation Procedure}

Firstly, the study tests the stochastic properties of the series employed for the variables specified in the model using complementary test of ADF and PP. The PP unit root test is employed to complement ADF for its greater reliability than the ADF due to robustness in the midst of serial correlation and hetersokedasticity (Hamilton, 1994). The unit root test for variables is carried out with both trend and intercept using the following specification:

$\Delta \mathrm{INS}_{\mathrm{t}}=\alpha_{0}+\beta_{1} \mathrm{INS}_{\mathrm{t}-1}+\beta_{2} \mathrm{~T}+\sum_{i=0}^{n} \varphi i \Delta \mathrm{INS}_{\mathrm{t}-i+} \varepsilon_{\mathrm{t}} \ldots \ldots \ldots \ldots \ldots$

Where, $\beta_{0}, \beta_{1}, \beta_{2}$ and $\varphi i \ldots \varphi_{\mathrm{n}}$ are parameters to be estimated, and $\varepsilon_{\mathrm{t}}$ is the disturbance error term.

The unit root tests are followed by the test of cointegration using the Johansen $(1988,1991)$ framework. The renowned Johanson's (1998) cointegration method is used to confirm the long-run relationship among the specified variables in the model. The Johansen Cointegration is one that modelled time series as reduced rank regression in which it computed the maximum likelihood estimates in the multivariate Cointegation model with Gaussian error terms. Thus, the Cointegration model is specified as:

$\Delta \mathrm{Z}_{\mathrm{t}}=\sum_{i=1}^{p-1} \mu+\Gamma_{\mathrm{i}} \Delta \mathrm{Z}_{\mathrm{t}-\mathrm{k}}+\Pi \mathrm{Z}_{\mathrm{t}-1}+\delta_{\mathrm{t}}$

Where $Z_{t}$ is an ( $\left.\mathrm{n} x 1\right)$ column vector of $\mathrm{p}$ variables; $\mu$ is an $(\mathrm{n} \times 1)$ vector of constant terms and $\Pi$ represent coefficient matrices; $\Delta$ is a difference operator; $k$ denotes the lag length and; $\varepsilon_{\mathrm{t}} \sim$ $\mathrm{N}(0, \Sigma)$. The coefficient matrix $\Pi$ is known as the impact matrix, and it contains information about the long-run relationships. The estimation of Johansen Cointegration specified in equation (3.5) follows that the residuals are used to compute two likelihood ratio test statistics: the trace test and maximal eigenvalue $(\lambda-\max )$ test. The trace test considers the hypothesis that the rank of $\Pi$ is less than or equal to $r$ cointegrating vectors (i.e there are at most $r$ cointegrating vector), and it is expressed as:

Trace $=-\mathrm{T} \sum_{i=r+1}^{n} \operatorname{In}(1-\lambda)$ 
Alternatively, the maximal eigenvalue test $(\lambda-\max )$ computes the null hypothesis that there are exactly $r$ cointegrating vectors in the system and it is given as:

$\lambda-\max =\operatorname{TIn}\left(1-\lambda_{\mathrm{r}}\right)$

The distributions for these tests are not given by the usual chi-square distributions. The asymptotic critical values for the two likelihood ratio tests are calculated via numerical simulations. The null hypothesis is rejected when the estimated likelihood ratio tests statistics exceeds critical values. Since each of the two tests have their strength and limitations, it is preferable to make inference using both tests.

\section{Presentation of Result and Analysis}

The summary of the result of correlation matrix analysis of the data used for the variables employed in the study is provided in the appendix 1 .

\subsection{Pre-estimation tests}

The complementary tests of unit root shown in table 4.1 reveals that all of the variables are non-stationary since they are all integrated at order $\mathrm{I} / 1$ and that at order one they are stationary at $1 \%$ level of statistical significance except rule of $(\mathrm{RoL})$ that is integrated at order $\mathrm{I} / 1$ but at $5 \%$ level of statistical significance.

Table 4.1: The Result of Unit Root Test

\begin{tabular}{|c|c|c|c|c|c|c|c|}
\hline \multirow[t]{2}{*}{ Variables } & \multirow{2}{*}{$\begin{array}{l}\text { Order of } \\
\text { integration }\end{array}$} & \multicolumn{2}{|c|}{ Critical Values } & \multicolumn{3}{|c|}{ Test Critical Values } & \multirow[t]{2}{*}{ Decsions } \\
\hline & & $\mathrm{ADF}$ & PP & $1 \%$ & $5 \%$ & $10 \%$ & \\
\hline INS. & $\mathrm{I}(1)$ & $-6.944 *$ & $-8.610^{*}$ & -4.297 & -3.570 & -3.220 & Stationary \\
\hline$\overline{\mathrm{AIC}}$ & $\mathrm{I}(1)$ & $-5.677 *$ & $-5.694 *$ & -4.285 & -3.563 & -3.212 & Stationary \\
\hline BQLT & $\mathrm{I}(1)$ & $-4.756^{*}$ & $-4.033 *$ & -4.297 & -3.568 & -3.220 & Stationary \\
\hline COR & $\mathrm{I}(1)$ & $-3.227 *$ & $-3.112^{*}$ & -3.662 & -2.960 & -2.620 & Stationary \\
\hline GACT & $\mathrm{I}(1)$ & $-5.698 *$ & $-9.924 *$ & -4.297 & -3.568 & -3.220 & Stationary \\
\hline GSTB & $\mathrm{I}(1)$ & $-4.370 *$ & $-4.953 *$ & -4.285 & -3.563 & -3.220 & Stationary \\
\hline RoL & $\mathrm{I}(1)$ & $-3.430 * *$ & $-3.380 * *$ & -3.662 & -2.960 & -2.620 & Stationary \\
\hline
\end{tabular}

Source: Author's Computation

The optimal lag length selected is one (1). Though, there is contention regarding lag selection criteria among the test frameworks, while the final prediction error (FPE) and Akaike information criterion (AIC) choses two (2) as the lag length, the Schwarz information criterion, Hannan-Quine information criterion and likelihood ratio (LR) chose one (1) as the lag length as shown in the appendix 2. Since three tests with one lag length dominate the other two tests with two lag length, the study chose one lag length as the optimal lag length.

\subsection{Estimation of the Results}

The results shown in both table 4.2 and 4.3 reported both maximum eigenvalue and trace statistics of Johansen Cointegration tests. The results suggest that, for the Trace test statistics there are seven (7) coitegrating equations at 0.05 levels of significance and for the maxeigenvalue test statistics, there are two (2) cointegrating equations at 0.05 level of significance 
between insecurity and all examined indicators of governance. This means there exist evidence of long-run relationship between insecurity and governance indicators in Nigeria.

Table 4.2: Unrestricted Cointegration Rank Test (Trace)

\begin{tabular}{lllll}
\hline $\begin{array}{l}\text { Hypothesized } \\
\text { No. of CE(s) }\end{array}$ & Eigenvalue & Trace Statistic & Critical Value (0.05) & Prob. \\
& \multicolumn{7}{l}{} & & \\
\hline None * & 0.842522 & 218.6306 & 150.5585 & 0.0000 \\
At most 1 & 0.772475 & 161.3281 & 117.7082 & 0.0000 \\
At most 2 & 0.689053 & 115.4328 & 88.80380 & 0.0002 \\
At most 3 & 0.591789 & 79.2206663 .87610 & 0.0015 & \\
At most 4 & 0.492711 & 51.44559 & 42.91525 & 0.0057 \\
At most 5 & 0.409155 & 30.40668 & 25.87211 & 0.0127 \\
At most 6* & 0.365335 & 14.09441 & 12.51798 & 0.0270 \\
\hline
\end{tabular}

Trace test indicates 7 cointegrating eqn(s) at the 0.05 level

$*$ denotes rejection of the hypothesis at the 0.05 level

**MacKinnon-Haug-Michelis (1999) p-values

\section{Table 4.3: Unrestricted Cointegration Rank Test (Maximum Eigenvalue)}

\begin{tabular}{lcccr}
$\begin{array}{l}\text { Hypothesized } \\
\text { No. of CE(s) }\end{array}$ & Eigenvalue & Statistic & Critical Value (0.05) & Prob. \\
\hline None * & 0.842522 & 57.30251 & 50.59985 & 0.0088 \\
At most 1 * & 0.772475 & 45.89528 & 44.49720 & 0.0350 \\
At most 2 & 0.689053 & 36.21213 & 38.33101 & 0.0858 \\
At most 3 & 0.591789 & 27.7750732 .11832 & 0.1549 & \\
At most 4 & 0.492711 & 21.03891 & 25.82321 & 0.1890 \\
At most 5 & 0.409155 & 16.31227 & 19.38704 & 0.1324 \\
At most 6 * & 0.365335 & 14.09441 & 12.51798 & 0.0270 \\
\hline
\end{tabular}

Source: Authors' Computation

\subsection{The Long-rum parameters}

Although, cointegration or long-run relationship between insecurity and the six indicators of governance has been established, however, the Johansen Cointegration did not offer the explanation on the magnitude of this relationship. In order to obtain the parameter estimate and the extent to which governance otherwise measured by the six indicators of governance impact on insecurity in Nigeria, fully modified ordinary least square (FMOLS) is employed. The result of the test is thus presented in table 4.4. As shown in the same table 4.4, all of the indicators of governance with exception of AIC (absence of internal conflict) impacted positively on insecurity in Nigeria making the governance (in a broad term) negating the theory. Taking individually:

Government stability (GSTB): It is revealed in the table 4.4 that government stability as an indicator of governance impacts positively on insecurity, though at insignificant level of statistics. This means that, $29.40 \%$ level of insecurity is caused by one per cent increase in the poor system of governance due to the less stability in government in Nigeria. Also, 
Government accountability (GACT) as an indicator of governance impacts positively on insecurity and at a statistical level of significance (0.0001). That is, $145.2 \%$ level of insecurity situation in Nigeria is ascribed to one per cent increase in the problem of governance due to poor accountability in the system of government in Nigeria. Similarly, Corruption (COR) as an indicator impact positively on insecurity and at a significant level of statistics. Impliedly, $199.7 \%$ level of insecurity situation in Nigeria is caused by one per cent increase in the level of poor governance due to hard-biting corruption in Nigeria. Bureaucratic quality (BQLT) as an indicator of governance has a significant positive impact on insecurity. This means that, one per cent increase in the level of poor government due to the problem of bureaucratic quality caused insecurity in Nigeria rise by $10.6 \%$. More so, rule of law (law and order) impact positively on insecurity and at significant level of statistics. This is by implication, one per cent increase in the level of poor governance due to less effective rule of law caused insecurity to increase by $106.3 \%$. Likewise, Absence of internal conflict (AIC) as an indicator of governance has a significant negative impact on insecurity.

\section{Table 4.4: Result of Long-run parameters (FMOLS)}

Dependent Variable: INS

Method: Fully Modified Least Squares

(FMOLS)

Sample: 19862018

Included observations: 32 after adjustment

Long-run covariance estimate (Bartlett kernel, Newey-West fixed-

bandwidth $=4.0000$ )

\begin{tabular}{|c|c|c|c|c|}
\hline Variables & \multicolumn{2}{|c|}{ Coefficients Standard Errors } & T-Stat. & Prob. \\
\hline GSTB & \multicolumn{4}{|c|}{29.3715527 .067481 .0851230 .2882} \\
\hline GACCT & \multicolumn{4}{|c|}{145.213531 .022684 .6808810 .0001} \\
\hline COR & \multicolumn{4}{|c|}{199.713091 .806352 .1753720 .0393} \\
\hline BQLT & \multicolumn{4}{|c|}{10.5656072 .211910 .1463140 .8848} \\
\hline AIC & \multicolumn{4}{|c|}{$-56.7848725 .27477-2.2467010 .0337$} \\
\hline ROL & \multicolumn{4}{|c|}{106.289859 .528591 .7855250 .0363} \\
\hline $\mathrm{C}$ & -657.972 & 379.9615 & -1.731681 & 0.0957 \\
\hline \multicolumn{5}{|c|}{$\mathrm{R}^{2} 0.589723$} \\
\hline \multicolumn{5}{|c|}{$\mathrm{R}^{2}$-Adjusted $\quad 0.491257$} \\
\hline \multicolumn{2}{|c|}{ S.E. of regression } & 96.00794 & & \\
\hline
\end{tabular}


Nonetheless, the $\mathrm{R}^{2}$-adjusted and standard error of regression depicts about $50 \%$ variations from regression line is captured by error term and $96 \%$ of variation of all explanatory variables is explained by the standard error of regression respectively as shown in the table 4.4.

\section{Discussion of Findings}

From the estimated results revealed in the table 4.4, there is evidence of poor governance prevailing in the country as all of the indicators of governance except absence of internal conflict have positive impact on insecurity which negates the principle of governance in establishing safe and secured economy under which socio-economic life can be safely pursued. Interestingly, among all the five indicators that impact positively on insecurity, government accountability, corruption and rule of law appeared significant causes of governance problem that breed insecurity in Nigeria and are discussed in the following orders:

Corruption: corruption positively impacting on insecurity in Nigeria is in agreement to the findings of Olaniyi and Ikechukwu (2019); Gabriel (2017) and by implication, the deliberate efforts of government to abate insecurity tension in country is thwarted by the prevalence of systemic corruption that has equally spread to most of the government functionaries designated to discharge constituted responsibilities and consequently making most part of the country unsecured for business and economic activities to thrive. A typical case of this development is above \$2billion US dollars arms deal otherwise referred to as Dasukigate where these amount that is officially appropriated for the procurement of firearms to fight and combat insurgency terrorising the country particularly in the north-eastern Nigeria is embezzled and shared among the politicians closed to the seat of power during the administration of President Goodluck Jonathan without minding the grave consequences it poses on insecurity in the country (Fumnanya, 2015).

Government accountability: This indicator of governance in Nigeria has positive impact on insecurity is supported by the findings of Ifeanyi (2014) and; Ewetan and Urhie (2014). Tracing back the incidence of insecurity to the post independent period particularly immediately after the civil war, inappropriate and unaccountable handling of firearms by the security departments of the country where the firearms and ammunitions that were meant for the execution of wars against both internal and external threats as well as proffering secured and safe environment slipped into the hands of miscreants and they used them to perpetrate crimes in the country is a product of government unaccountability (Ewetan and Urhie, 2014). Similarly, the failure of government to investigate bloody sectarian clashes that consumed hundreds of lives in late 2008 and 2009; much less hold accountable, members of the security forces implicated in numerous incidents of extra judicial killings, torture, and extortion are some of the glaring incidences pointing to the lack of government accountability in the country that is frustrating the socioeconomic well-being of the country (Human Right Report-HRR, 2010). Also, the recent case of Hamisu Bala (a.k.a Wadume), the Taraba state kidnap kingpin who is allegedly connived with an Army captain and killed three policemen and a civilian in order to gain escape from arrest is another good example of government accountability that's lacking in the governance system in Nigeria thereby incentivizing insecurity crimes and consequently making the country unsafe for socioeconomic activities to thrive (Femi, 2020).

Rule of law (law and order): As an indicator of governance impacted positively on insecurity at statistical level of significance is supported by the opinion revelation by John (2017) that there are long ties between the ethnic and religion violence and impunity in Nigeria. Similarly, 
the Nigerian ex-president Dr. Goodluck Jonathan opined that failure to enforce the law on the perpetrator of violent crime in Nigeria is attributed to the reason for recurring incident of ethnic and religion clashes as well as roofing heinous criminal acts in the country (Jonathan, 2017). A typical example of this opinion is the case of prosecuted and apprehended multi-million dollars Lagos kidnappers (Evans) but yet, sees no judgement and conviction for close to two years now, and many of the prosecuted Boko-haram terrorists and Niger-Delta militants without made to face full wrath of law instead they are granted amnesty and became freed in the society (Gabriel, 2017).

\section{Summary, Conclusion and Recommendations}

This study empirically examined the impact of governance on insecurity in Nigeria by splitting governance to six indicators and investigated impact of each of the indicator on insecurity to empirically establish which of the indicator of governance that is mostly causing insecurity in Nigeria. The study employed Johansen cointegration and fully modified ordinary least squares after establishing the stationarity properties of the series employed for the variables specified in the model at the pre-estimation tests using complementary tests of ADF and PP. And the post diagnostic tests show that the obtained result is freed from those problems that lead to spurious regression result.

On this notes, the study found the existence of long-run relationship between governance indicators and insecurity as revealed by the result of estimated Cointegration test. The results of long-run parameters estimated using FMOLS reveal that all the indicators of governance are of positive impact on insecurity in Nigeria except absence of internal conflict (AIC) that negatively impacted on insecurity in Nigeria negating the principle of theory underpinning the study and governance system in relation to insecurity. Also, among the five indicators of governance that have positive impact on insecurity, government accountability (GACT), corruption (COR) and rule of law (RoL) are of significant impact on insecurity in Nigeria.

Therefore, some of the recommendations offered by the study are:

(i) Advancing the country's anti-corruption agency with more impetus to match the changing ways of perpetrating corruption among the public office holders particularly the top rank officers of the Nigerian security departments and political office holders as a way of entrenching good governance thereby abating insecurity in country.

(ii) Full application of law on any of the accused individual found guilty to the law of land irrespective of social status and connections should be enforced so as to serve as deterrent to any intending individuals to commit crime.

(iii) Systemic enlightenment of the citizens on the responsibilities like provision of security of lives and properties owed to them by the government as a means of holding any government accountable for its actions particularly in the democratic system of government where politicians periodically go to citizens to seek for their mandates to win elections. 


\section{References:}

Abdullahi, D. (2012). Good governance as panacea to socio-economic crises in Nigeria. IOSR Journal of Business and Management,2(3), 36-40.

Abdulrasheed, I., Amir, A. \& Matazu, S. S. (2018). The incidence and impact of cattle rustling in some rural communities of Katsina state, Nigeria. FUDMA Journal of Sciences (FJS), 2(2), 288-296.

Achumba, I. C., Ighomereho, O. S. \& Akpor-Robaro, O. M. (2013). Security challenges in Nigeria and the implications for business activities and sustainable development. Journal of Economics and Sustainable Development, 4(2), 79-99.

Adamu, A. \& Rasheed H. Z. (2016). Effects of insecurity on the internally displaced persons (IDPs) in northern Nigeria: Prognosis and diagnosis. Global Journal of Human and Social Science, 6(1), 1-6.

Akinola, A. B. (2016). Contemporary security threats and terrorism on socio-economic and political development of Nigeria. Direct Research Journal of Social Science and Educational Studies, 3 (1), 1-8.

Andersen, M. L. \& Taylor, H. F. (2006). Sociology: Understanding a diverse society. Thomson Wadsworth: Britain.

Beland, D. (2015). The political construction of collective insecurity. Centre for European Studies Working Paper Series 126, Lagos, Nigeria.

Buzan, B. (1991). New patterns of global security in the 21st Century. International Affairs, 67 (3), 433-452.

Central Bank of Nigeria (2016). Functional classification of Federal government expenditure in Nigeria. CBN Publication, Nigeria.

Evans, O. \&Kelikume, I. (2018). The effects of foreign direct investment, trade, aid, remittances and tourism on welfare under terrorism and militancy. International Journal of Management, Economics and Social Sciences, 7(3): 206-232.

Ewetan, O.O. \& Urhie, E. (2014). Insecurity and Socio-Economic Development in Nigeria. Journal of Sustainable Development Studies, 5(1), 40-63.

Femi, O. (2020). Wadume, Taraba kidnap kingpin', charged with terrorism. Thecablenews.com Available on: https://www.thecable.ng/wadume-taraba-kidnap-king-pin-charged-withterrorism

Fumnanya, A. (2015). Dasukigate: Break down of alleged misappropriation $\$ 2.1 \mathrm{bn} . .$. Venturesafrica.com. Retrieved on $14^{\text {th }}$ of December, 2015 from: venturesafrica.com/dasukigate-here-is - breakdown-of-the-misappropriation-of-2-antfor-arms-deal-by-dasuki-and-others/

Gabriel, E. O. (2017). Determinant of human security in Nigeria and their impacts on economic growth. A Working Paper; Nigeria Economic Society's South-South Economic Conference (SSREC). November 6th-8th, 2017, Port-Harcourt, Nigeria. 
Global Terrorism Index (2015). Measuring and understanding the impact of terrorism. Institute of economics and peace. Available on: http://economicsandpeace.org/wpcontent/uploads/2015/11/Global-Terrorism-Index2015.pdf

Hamilton, J. D. (1994). Time series analysis. Princeton University Press, Princeton, New Jersey.

Herbert, C. E. \& Michael, I. U. (2014). Governance, national security and economic development in Nigeria: A political diagnosis of boko haram insurgence. Mediterranean Journal of Social Sciences, 5(17), 31-38.

HRR (2010). The abusers' reaction: intensifying attacks on Human Rights defenders and institutions. Retrieved from: https://www.hrw.org/world-report/2010/countrychapters/nigeria

Ibrahim, A.A. (2013). Issues in security, good governance and its challenges to economic growth and development. Mediterranean Journal of Social Sciences, 4(13), 187-191.

ICRG (2016). Political risk ratings for 140 countries: 1984-2017. Available on: https://www.prsgroup.com

Ifeanyi, C. (2014). The causes and effects of insecurity in Nigeria: The challenges and relevance of the Nigerian Police Force as a panacea. M.Sc. thesis submitted to the department of public administration, University of Nigeria, Nsuka.

Ikelegbe, A. (2006). Beyond the threshold of civil struggle: Youth militancy and the militialization of the resource conflicts in the Niger-Delta region of Nigeria. African Study Monographs 27(3): 87-122.

Joda, M. F. \& Abdulrasheed, O. (2015). Effects of insurgency on girls' education in northeastern Nigeria, European Journal of Education and Development Psychology, 3, (1), 4450 .

Johansen, S. (1988). "Statistical analysis of co-integrating vectors", Journal of Economic Dynamics and Control 12, 231- 254.

Johansen, S. (1991). "Estimation and Hypothesis Testing of Cointegration Vectors in Gaussian Vector Autoregressive Models". Econometrica 59, 1551-1580.

Jonathan, G. E. (2017). What Ex-president Jonathan told U.S about Nigerian Christian? Nigerian president address at US congress' house subcommittee on Africa. Premiumstimes.comRetrieved on $2^{\text {nd }}$ February, 2017 from: https://www.premiumstimesng.com/news/top-news/222394-ex-president-jonathan-toldu-s-lawmakers-nigeria-christians-full-speech.html

John, C. (2017). Nigerian violence and impunity. Council on foreign relations. Retrieved on $17^{\text {th }}$ February, 2017 from: www.cfr.org/blog/nigerian-violence-and-impunity

Ladan, S. I. (2019). Analysis of contemporary insecurity in Katsina state, Nigeria. Direct Research Journal of Social Science and Educational Studies, 6 (7), 95-102.

Merton, R. K. (1938). Social structure and anomie. American Sociological Review, 3: 672-82. 
Ngwama, J. C. (2014). Kidnapping in Nigeria: An emerging social crime and the implications for the labour market. International Journal of Humanities and Social Science, 4(1): $133-45$.

Okoli, A. C. \& Nachanaa, D. A. (2016). Militancy and the dilemma of petro-rentier criminality in the Niger Delta. Online Journal of Arts, Management \& Social Sciences , 1(1): 219237.

Oladipo, S.B. (2013). Vision 20-20-20 and the menace of vandalism: Xlibris Corporation.

Olawale, I. (2003). Youth, culture, state collapse and nation building in West Africa: The nexus revisited. Paper presented at the Council for the Development Social Science Research in Africa (CODESRIA), West Africa Sub-Regional Conference, 6-7 September. Cotonou, Benin.

Olaniyi, E. \& Ikechukwu, K. (2019). Impact of poverty, unemployment, inequality, corruption and poor governance on Niger-Delta militancy, boko haram and Fulani herdsmen attacks in Nigeria. International Journal of Management, Economics and Social Sciences, 8(2), 58-80.

Olawale, I. (2003). Youth, culture, state collapse and nation building in West Africa: The nexus revisited. Paper presented at the Council for the Development and Social Science Research in Africa (CODESRIA), West Africa Sub-Regional Conference, 6 - 7 September. Cotonou, Benin Republic.

Olu-Adeyemi, L. (2017). Deprivation, frustration and aggression: an interrogation of Fulani herdsmen terror in Nigeria. Advances in Social Sciences Research Journal, 4(15): 1-13.

Olusegun, A. J. (2016). Economic growth amidst insecurity: The Nigerian experience. Research Journal of Finance and Accounting, 7(7), 56-71.

Onime, B. E. (2018). Insecurity and economic growth in Nigeria: A diagnostic review. European Scientific Journal, 14(4), 377-391.

Osagie, J., Fred, A. \& Samuel, E. (2010). Causes of conflicts in the Niger Delta region of Nigeria as expressed by the youth in Delta State. Procedia-Social and Behavioral Sciences , 5, 82-89.

Polinsky, A. M. \& Shavell, S. (2001). Corruption and optimal law enforcement. Journal of Public Economics, 81(1)1-24.

Tharanga, M. (2018). Impact of governance on economic growth. Munich Personal RePEc Archive (MPRA), 1-51. 


\begin{tabular}{|c|c|c|c|c|c|c|}
\hline Variables & INS & AIC & BQLT & COR & GACT & $\begin{array}{l}\text { GSTB } \\
\text { ssRoL }\end{array}$ \\
\hline $\mathrm{NS}$ & 1.000000 & & & & & \\
\hline AIC & -0.425222 & 1.000000 & & & & \\
\hline BQLT & -0.381167 & 0.485517 & 1.000000 & & & \\
\hline COR & -0.308531 & 0.339443 & 0.658704 & 1.000000 & & \\
\hline GACT & 0.706386 & -0.403070 & -0.356342 & -0.417130 & 1.000000 & \\
\hline GSTB & 0.076990 & -0.001392 & -0.517715 & -0.565034 & -0.186687 & 1.000000 \\
\hline RoL & -0.121868 & 0.737268 & 0.079480 & -0.032032 & -0.239148 & 0.439148 \\
\hline
\end{tabular}

Source: Author's Computation

\section{Appendix 2: Lag Selection Criteria}

\begin{tabular}{lcccccr}
\hline Lag & LogL & LR & FPE & AIC & SC & HQ \\
\hline 0 & -339.7913 & NA & 12.2883522 .3736322 .6974422 .47919 & & \\
1 & $-159.0318268 .2239 * 0.00271613 .8730216 .46345 * 14.71743 *$ & & \\
2 & -101.3447 & 59.54790 & $0.002647 *$ & $13.31256^{*}$ & 18.16962 & 14.89584 \\
\hline
\end{tabular}

Source: Author's computation 